\title{
Sylvain Ledda, Hernani et Ruy Blas. De Flamme et de
}

sang

\section{Lise Sabourin}

\section{(2) OpenEdition}

1 Journals

Édition électronique

URL : http://journals.openedition.org/studifrancesi/7988

DOI : ERREUR PDO dans /localdata/www-bin/Core/Core/Db/Db.class.php L.34 : SQLSTATE[HY000]

[2006] MySQL server has gone away

ISSN : 2427-5856

Éditeur

Rosenberg \& Sellier

Édition imprimée

Date de publication : 1 juillet 2009

Pagination : 418

ISSN : 0039-2944

\section{Référence électronique}

Lise Sabourin, «Sylvain Ledda, Hernani et Ruy Blas. De Flamme et de sang », Studi Francesi [En ligne], 158 (LIII | II) | 2009, mis en ligne le 30 novembre 2015, consulté le 07 janvier 2021. URL : http:// journals.openedition.org/studifrancesi/7988; DOI : https://doi.org/10.4000/studifrancesi.7988

Ce document a été généré automatiquement le 7 janvier 2021.

\section{(c) $($ ) $\odot$ (8)}

Studi Francesi è distribuita con Licenza Creative Commons Attribuzione - Non commerciale - Non opere derivate 4.0 Internazionale. 


\title{
Sylvain Ledda, Hernani et Ruy Blas. De Flamme et de sang
}

\author{
Lise Sabourin
}

\section{RÉFÉRENCE}

SYLVAIN LEDDA, Hernani et Ruy Blas. De Flamme et de sang, préface de Florence NAUGRETTE, Toulouse, Presses Universitaires du Mirail, «Amphi 7 Lettres», 2008, pp. 190.

1 À l'occasion de leur mise au concours d'agrégation 2009, Sylvain Ledda, auteur d'une thèse récente à propos de la représentation de la mort sur la scène romantique, Des Feux dans l'ombre (Champion, 2009), fait paraître un ouvrage bien organisé en quatre parties sur Hernani et Ruy Blas.

2 Il rappelle d'abord dans un mouvement intitulé «Pleins Feux» (pp. 21-57) les conditions de création et de représentation des deux pièces, qui ne font pas qu'accomplir le programme de la préface de cromwell, mais répondent aussi, chacune dans sa spécificité, aux recherches entreprises dès l'Empire pour la rénovation des formes dramatiques.

3 Puis il étudie «L'Espagne d'Hernani et Ruy Blas: vérité, fiction, miroir» (pp. 59-105). La connaissance hugolienne de la comedia du Siècle d'or (souvenir du Cervantès picaresque et grotesque, quiproquo de séduction du Burlador) rejoint la source cornélienne du Cid pour opérer une véritable «appropriation de l'identité culturelle d'un pays étranger grâce à la puissance de l'imaginaire» (p. 67).

4 «L'histoire en crise» (pp. 107-142) constitue un «beau et mélancolique spectacle» (préface de Ruy Blas), propice à une sémiotique poétique, chaque détail ayant sa force symbolique pour marquer le conflit entre les «derniers rehauts de la féodalité et l'expansion vers les temps modernes» (p. 112).

5 Enfin par une analyse de la «Dramaturgie: le spectacle romantique» (p. 143-177), axée notamment sur le sens du finale quasi opératique et l'existence de lamentos de 
l'individu jeté par sa quête de beauté et de liberté dans le combat contre les petitesses de la médiocrité, Sylvain Ledda montre comment chez Hugo «l'expression du sublime naît de l'adéquation entre une image pathétique et la ferveur lyrique du dialogue» (p. 176).

6 Ce livre fourmille de formulations brillantes qui donnent total relief à la scrutation, minutieuse et pertinente, de ces deux grands drames hugoliens. 